\title{
Distribution of Hepatitis C Virus Genotypes in Aydın Province
}

\author{
Aydın Ilinde Hepatit C Virus Genotiplerinin Dağılımı
}

\author{
๑ Yasin TIRYAKI, ๑ Alev ÇETIN DURAN, ๑ Osman Olcay ÖZÇOLPAN
}

Aydın State Hospital, Laboratory of Microbiology, Aydın, Turkey

\begin{abstract}
Objectives: In this study, we evaulated the distribution and alteration of hepatitis $\mathrm{C}$ virus (HCV) genotypes throughout years which has a clinical importance in the treatment and follow-up.

Materials and Methods: Test results obtained from blood samples sent to the molecular microbiology laboratory at Aydın State Hospital for HCV genotype determination were analyzed retrospectively. A total of 182 samples collected between 2014 and 2018 were enrolled in the study. The determination of genotype and viral load of the samples were performed by real time polymerase chain reaction.

Results: $53.8 \%(98 / 182)$ of the samples were collected from male patients and $46.2 \%(84 / 182)$ from female patients. The mean age of the patients was $58.5 \pm 15.5$ years. $69.2 \%$ of the samples were genotype 1b, 18.1\% - genotype 1a, 2.2\% - genotype 1 (those different from subtype $1 \mathrm{a}$ and $1 \mathrm{~b}), 1.7 \%$ - genotype $2,7.2 \%$ genotype 3 , and $1.7 \%$ of the samples were genotype 4 .

Conclusion: In the present study, genotype 1 was the most common genotype (89.5\%). Additionally, we have observed a decrease in the frequency of genotype $1 \mathrm{~b}$ and a slightly increase in the frequency of other genotypes. Determination of HCV genotypes is important for treatment and prognosis of HCV infections.

Keywords: Hepatitis C virus, hepatitis C virus genotypes, epidemiology
\end{abstract}

\section{$0 ̈ Z$}

Amaç: Çalışmamızda, hepatit C virüs (HCV) enfeksiyonunun tedavi ve takibinde önemli olan, HCV genotiplerinin dağılımı ve yıllar içindeki değişimi incelenmiştir.

Gereç ve Yöntemler: Aydın Devlet Hastanesi Moleküler Mikrobiyoloji Laboratuvarı'na 2014-2018 yılları arasında HCV genotip tayini için gönderilen kan örneklerinden elde edilen test sonuçları retrospektif olarak incelendi. Toplam 182 örneğin viral yükleri ve genotip tayini gerçek zamanlı polimeraz zincir reaksiyonu yöntemi ile belirlendi.

Bulgular: Örneklerin 98'i (\%53,8) erkek, 84'ü $(\% 46,2)$ kadın hastalara ait olup, yaş ortalaması $58,5 \pm 15,5$ olarak hesaplanmıştı. Örneklerin \%69,2'sinde genotip 1b, \%18,1'inde genotip 1a, \%2,2'sinde genotip 1 (1a, $1 \mathrm{~b}$ dışı), \%1,7'sinde genotip 2, \%7,2'sinde genotip 3 ve \% 1,7'sinde genotip 4 saptanmıştır.

Sonuç: Çalışmamızda, en yüksek oranda genotip 1 (\%89,5) rastlanmıştır. Genotip 1b oranında yıllar içinde azalma, diğer genotiplerde ise ılımlı bir artış saptanmıştır. HCV genotiplerinin takibi, tedavi ve prognoz açısından önemli olduğu gibi, epidemiyolojik açıdan da yol göstericidir.

Anahtar Kelimeler: Hepatit C virüs, hepatit C virüs genotipleri, epidemiyoloji

Tiryaki Y. Çetin Duran A. Özçolpan 00. Distribution of Hepatitis C Virus Genotypes in Aydın Province. Viral Hepat J. 2018;24:70-74.

\section{Introduction}

Hepatitis C virus ( $\mathrm{HCV}$ ) is an enveloped, single-stranded positive-sense RNA virus classified in the genus Hepacivirus of the family Flaviviridae (1). HCV infection is an important global public health problem (2). The virus is usually transmitted through blood transfusion, surgical and dental procedures, intravenous drug use and sexual intercourse $(3,4,5)$. HCV infection becomes chronic in approximately $75 \%-85 \%$ of cases. Cirrhosis develops in approximately $20-30 \%$ of patients over 20 years of HCV infection. Among these patients, hepatocellular carcinoma develops at a rate of $1 \%-4 \%$ (6). According to the World Health Organization, globally, an estimated 71 million people have chronic hepatitis $\mathrm{C}$ infection and approximately 399.000 people die each year from hepatitis $C$, mostly from cirrhosis and hepatocellular carcinoma (7). In Turkey, it is estimated that around 1 million people are infected with HCV (8).

Address for Correspondence: Yasin Tiryaki MD, Aydın State Hospital, Laboratory of Microbiology, Aydın, Turkey 
HCV has 7 different genotypes and more than 60 subtypes $(9,10)$. HCV genotypes 1,2 and 3 are the most prevalent globally whereas genotype 4 is common in North Africa and Middle East, genotype 5 in South Africa and genotype 6 is common in Southeast Asia (2,11). Genotype 1 is the most common (46.2\%) HCV genotype in the world followed by genotype 3 (30.1\%). Genotype 2, 4 and 6 account for $22.8 \%$ of cases and genotype 5 is found in less than $1 \%$ of cases (11). Determination of geographical distribution of HCV genotypes is critical in the development of rational therapy protocols (12).

In this study, we aimed to determine the distribution of $\mathrm{HCV}$ genotypes in a five-year period in our region.

\section{Materials and Methods}

The results of HCV genotyping performed between 2014 and 2018 in 182 HCV RNA-positive patients in Aydın State Hospital were retrospectively evaluated. Repeated results from the same patients were excluded. Ethics committee approval was not required due to the retrospective design of the study.

Viral nucleic acid extractions were performed by a Magnesia 16 automated analyzer (Anatolia Geneworks, Turkey) using "Magnesia viral nucleic acid extraction kit EP" (Anatolia Geneworks, Turkey). Quantitation of viral nucleic acids was performed by real timepolymerase chain reaction (RT-PCR) targeting $5^{\prime}$ UTR region in a Montania 4896 analyzer (Anatolia Geneworks, Turkey) using "Bosphore HCV Quantification Kit V2" (Anatolia Geneworks, Turkey). This assay had an analytical sensitivity of $25 \mathrm{IU} / \mathrm{mL}$ and a linearity range of $10^{1}-10^{9} \mathrm{IU} / \mathrm{mL}$. HCV genotyping [genotypes $1 \mathrm{a}, 1 \mathrm{~b}, 1$ (those different from subtype $1 \mathrm{a}$ and $1 \mathrm{~b}), 2,3,4,5,6$ ] was performed by RT-PCR targeting NS5B region in a Montania 4896 analyzer (Anatolia Geneworks, Turkey) using "Bosphore HCV Quantification Kit V3" (Anatolia Geneworks, Turkey). All assays were performed according to the manufacturer's instructions.

\section{Results}

$53.8 \%$ (98/182) of the samples were collected from male patients (mean age: $55.8 \pm 15.9$ years) and $46.2 \%$ (84/182) of the samples were collected from female patients (mean age: $61.7 \pm 14.4$ years). The mean age of the study population was $58.5 \pm 15.5$ years. HCV RNA levels ranged between 694 and $31.580 .000 \mathrm{IU} /$ $\mathrm{mL} .69 .2 \%(126 / 182)$ of the samples were genotype $1 \mathrm{~b}, 18.1 \%$
(33/182) 1a, 2.2\% (4/182) - 1 (those different from subtype 1a and 1b), 1.7\% (3/182) - genotype 2, 7.2\% (13/182) - genotype 3 and $1.7 \%(3 / 182)$ were genotype 4 (Figure 1).

Distribution of HCV genotypes by years (2014-2018) is presented in Table 1. Gender and age distribution of HCV genotypes between 2014 and 2018 are presented in Table 2.

There were 11 foreign national patients in this study. The nationalities and HCV genotypes of these patients are summarized in Table 3. Genotype 1b (72.7\%) was the predominant genotype in this group.

\section{Discussion}

Genotype $1 \mathrm{~b}$ is the most common HCV genotype in Turkey. Recent studies revealed that there has been a decline in the prevalence of HCV genotype $1 \mathrm{~b}$ infections while an increase in the prevalence of infections caused by other genotypes. This alteration may be due to immigrants, touristic activities and different risk factors for HCV infection, as well as increased safety procedures in medical practice. Table 4 shows the results of some of the HCV genotyping studies in Turkey $(13,14,15,16,17,18,19,20,21,22,23,24$, $25,26,27)$.

In this study, HCV genotype 1 (89.5\%) was found the most common genotype in Aydın. However, we have observed a decrease in the frequency of genotype $1 \mathrm{~b}$ infection throughout years while a slight increase in genotype 1a infection. Additionally, there has been an increase in the genotype diversity over years particularly in genotype 3 and genotype 4, respectively.

Among foreign nationals (Azerbaijan, Russia, Syria, Ukraine, Romania, Mongolia) enrolled in this study, patients infected with genotype 3 were from Syria and Ukraine while those with

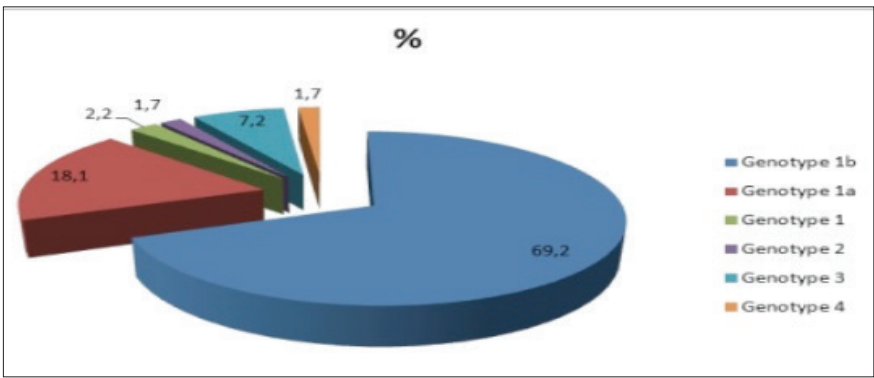

Figure 1. Distribution of hepatitis $C$ virus genotypes

Table 1. Distribution of hepatitis C virus genotypes by years (2014-2018)

\begin{tabular}{|c|c|c|c|c|c|c|c|c|}
\hline \multirow{3}{*}{ Year } & \multicolumn{8}{|c|}{ HCV genotypes } \\
\hline & \multicolumn{4}{|c|}{ Genotype 1 n (\%) } & \multirow{2}{*}{ Genotype 2 n (\%) } & \multirow{2}{*}{ Genotype 3 n (\%) } & \multirow{2}{*}{ Genotype 4 n (\%) } & \multirow{2}{*}{ Total n } \\
\hline & $1 a$ & $1 \mathrm{~b}$ & 1 & Genotype 1 Total & & & & \\
\hline 2014 & $3(42.9)$ & $4(57.1)$ & - & $7(100.0)$ & - & - & - & 7 \\
\hline 2015 & 4 (12.9) & $25(80.6)$ & - & $29(93.5)$ & $1(3.2)$ & $1(3.2)$ & - & 31 \\
\hline 2016 & $7(19.4)$ & $26(72.2)$ & $1(2.8)$ & $34(94.4)$ & - & $2(5.6)$ & - & 36 \\
\hline 2018 & $5(31.3)$ & $10(62.5)$ & - & 15 (93.8) & - & $1(6.2)$ & - & 16 \\
\hline Total & $33(18.1)$ & $126(69.2)$ & $4(2.2)$ & $163(89.5)$ & $3(1.7)$ & $13(7.2)$ & $3(1.7)$ & $182(\mathbf{1 0 0 . 0})$ \\
\hline
\end{tabular}


genotype 4 were from Syria (Table 3). Touristic activities in the region and Syrian refugees may be the cause of increase in the diversity of HCV genotypes in Aydın province. Studies performed in various regions of Turkey including Mediterranean, Aegean and southeast Anatolia regions shows that in the areas exposed to immigrant and touristic activities, genotype 1 was still responsible for the vast majority of cases, however, the prevalence of the other genotypes was higher than in the other regions of Turkey (Table 4)

Table 2. Gender and age distribution of hepatitis C virus genotypes between 2014 and 2018

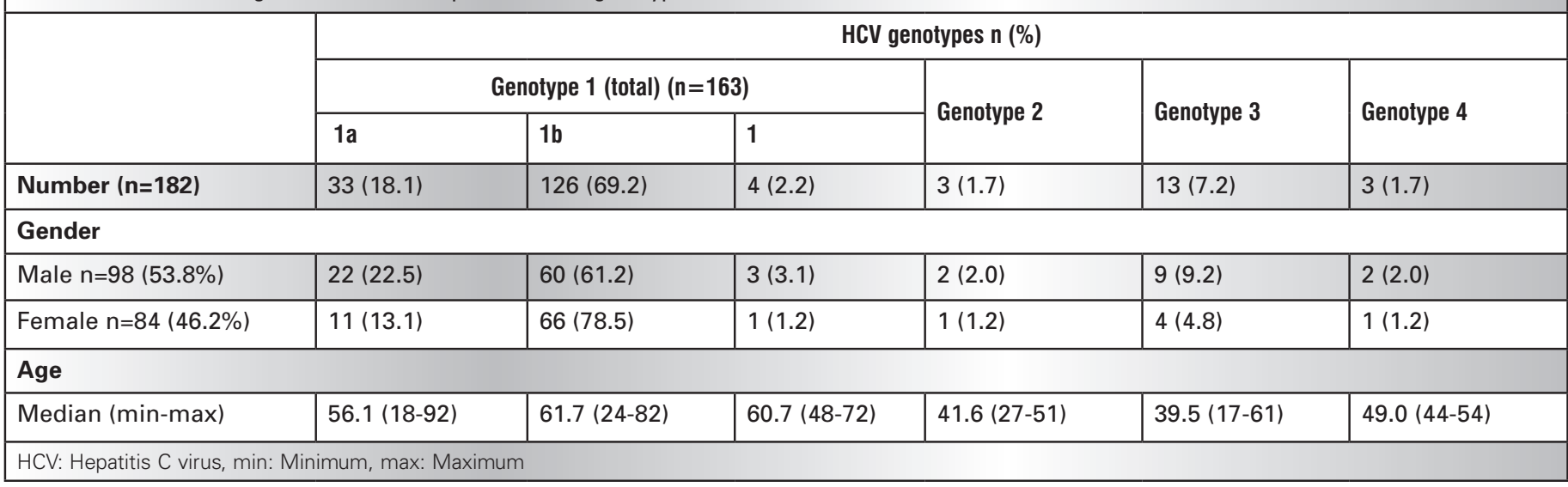

Table 3. Distribution of hepatitis C virus genotypes in foreign nationals

\begin{tabular}{|l|l|l|l|l|l|}
\hline \multicolumn{5}{|l|}{} & \multicolumn{5}{c|}{ HCV genotypes $\mathbf{n}(\%)$} \\
\hline Country & Number & Genotype 1b & Genotype 2 & Genotype 3 & Genotype 4 \\
\hline Azerbaijan & $4(36.3)$ & $4(36.3)$ & - & - & - \\
\hline Russia & $2(18.2)$ & $2(18.2)$ & - & - & - \\
\hline Syria & $2(18.2)$ & - & - & $1(9.1)$ & $1(9.1)$ \\
\hline Ukraine & $1(9.1)$ & - & - & - & - \\
\hline Romania & $1(9.1)$ & $1(9.1)$ & - & - & - \\
\hline Mongolia & $1(9.1)$ & $1(9.1)$ & - & - & $2(18.2)$ \\
\hline Total & $11(100.0)$ & $8(72.7)$ & - & $1(9.1)$ \\
\hline
\end{tabular}

Table 4. Results of some of the hepatitis C virus genotyping studies in Turkey

\begin{tabular}{|c|c|c|c|c|c|c|c|c|c|c|}
\hline $\begin{array}{l}\text { Study } \\
\text { (Reference) }\end{array}$ & Year & Province & $\begin{array}{l}\text { Number } \\
\text { (n) }\end{array}$ & \multicolumn{7}{|c|}{ Genotypes } \\
\hline Abacioglu et al. (13) & 1995 & Izmir & 89 & $84(94.4)$ & (19.1) & (75.3) & $3(3.4)$ & - & $2(2.2)$ & - \\
\hline Yarkin and Hafta (14) & 2000 & Adana/Mersin & 62 & $60(96.7)$ & $(14.5)$ & (82.2) & $2(3.3)$ & - & - & - \\
\hline Bozdayi et al. (15) & 2004 & Ankara & 365 & $349(95.0)$ & $(11.0)$ & $(84.0)$ & $10(3.0)$ & $3(1.0)$ & $3(1.0)$ & - \\
\hline Gokahmetoglu et al. (17) & 2011 & Kayseri & 146 & $90(61.7)$ & (3.4) & $(52.8)$ & $4(2.7)$ & - & $52(35.6)$ & - \\
\hline Buruk et al. (18) & 2013 & Trabzon & 304 & $282(92.8)$ & (5.3) & (87.5) & $5(1.6)$ & $15(4.9)$ & $2(0.7)$ & - \\
\hline Altuglu et al. (19) & 2013 & Izmir & 535 & $499(93.3)$ & (12.9) & $(80.4)$ & $8(1.5)$ & $20(3.7)$ & $8(1.5)$ & - \\
\hline Saglik et al. (20) & 2014 & Antalya & 422 & $352(83.4)$ & $(14.7)$ & (63.3) & $15(3.5)$ & 47 (11.1) & $7(1.6)$ & - \\
\hline Kuscu et al. (21) & 2014 & Adana & 369 & $289(78.3)$ & - & - & $23(6.2)$ & $54(14.6)$ & $3(0.8)$ & - \\
\hline Duran et al. (25) & 2016 & Adana & 119 & $85(71.4)$ & $(12.6)$ & $(58.8)$ & $9(7.6)$ & $20(16.8)$ & $4(3.4)$ & $1(0.8)$ \\
\hline Balin et al. (26) & 2017 & Elazığ & 71 & $62(87.3)$ & - & - & $2(2.8)$ & $7(9.9)$ & - & - \\
\hline Harman et al. (27) & 2017 & Gaziantep & 160 & $157(98)$ & - & $(98.0)$ & $1(0.75)$ & $2(1.25)$ & - & - \\
\hline Presented study & $\begin{array}{l}2014- \\
2018\end{array}$ & Aydın & 182 & $163(89.5)$ & $(18.1)$ & $(69.2)$ & $3(1.7)$ & $13(7.2)$ & $3(1.7)$ & - \\
\hline
\end{tabular}


There are regional differences in the distribution of $\mathrm{HCV}$ genotypes in our country. The prevalence of HCV genotype 4 has been reported to be $35 \%$ in Kayseri $(17,24)$ while there has been an obvious increase in infections caused by genotype 3 in the cities of southern parts of Turkey, such as Adana and Kahramanmaraş. In this patient population, intravenous drug abuse is relatively frequent $(21,22,25)$. Genotype 5 infections are being reported in Syrian refugees (25).

Even though the frequency of genotype 1 , which is associated with poor prognosis, is frequent in Turkey (85-90\%), recent studies indicated a decrease in genotype 1 with an increase in other genotypes and regional increase in some genotypes.

\section{Study Limitations}

We conducted a retrospective study of the records. For these reason, there are some limitations. Some data, including possible transmission routes and risk factors, have not been obtained. Our data supports the dominance of genotype $1 \mathrm{~b}$ infections in the area. However, there is an increase in the rate of infections caused by other genotypes.

\section{Conclusion}

As a result, data have to be updated periodically not only for epidemiological purposes but also and more importantly for prognosis and treatment.

\section{Ethics}

Ethics Committee Approval: Retrospective study.

Informed Consent: Retrospective study.

Peer-review: Externally and internally peer-reviewed.

\section{Authorship Contributions}

Surgical and Medical Practices: O.O.Ö., Concept: Y.T., Design: A.Ç.D. Data Collection or Processing: O.O.Ö., Analysis or Interpretation: A.Ç.D., Literature Search: Y.T., Writing: Y.T.

Conflict of Interest: No conflict of interest was declared by the authors.

Financial Disclosure: The authors declared that this study received no financial support.

\section{References}

1. Simmonds P, Becher P, Bukh J, Gould EA, Meyers G, Monath T, Muerhoff S, Pletnev A, Rico-Hesse R, Smith DB, Stapleton JT; Ictv Report Consortium. ICTV Virus Taxonomy Profile: Flaviviridae. J Gen Virol. 2017;98:2-3.

2. Gower E, Estes C, Blach S, Razavi-Shearer K, Razavi H. Global epidemiology and genotype distribution of the hepatitis $\mathrm{C}$ virus infection. J Hepatol. 2014;61:45-57.

3. Chan DP, Lee KC, Lee SS, Tan TY. Community-based molecular epidemiology study of hepatitis $C$ virus infection in injection drug users. Hong Kong Med J. 2017;23:27-30.

4. Gupta E, Bajpai M, Choudhary A. Hepatitis C virus: Screening, diagnosis, and interpretation of laboratory assays. Asian J Transfus Sci. 2014;8:19-25

5. Ishii S, Koziel MJ. Immune responses during acute and chronic infection with hepatitis C virus. Clin Immunol. 2008;128:133-147.

6. Aygen B, Demirtürk N, Türker N, Asan A, Eraksoy H, Gürbüz $Y$, Inan D, Keten D, Koçulu S, Öncü S, Özkaya D, Saltoglu N, Sayan M,
Süer K, Şener A, Tekin S, Tuna N, Yazıcı S. Management of chronic hepatitis $\mathrm{C}$ virus infection: $\mathrm{A}$ consensus report of the study group for viral hepatitis of the Turkish society of clinical microbiology and infectious diseases-2017 Update. Klimik Derg. 2017;30:2-36.

7. Hepatitis C. World Healt Organization. http://www.who.int/newsroom/fact-sheets/detail/hepatitis-c

8. Tozun N, Ozdogan O, Cakaloglu Y, Idilman R, Karasu Z, Akarca U, Kaymakoglu S, Ergonul O. Seroprevalence of hepatitis B and C virus infections and risk factors in Turkey: a field-work TURHEP study. Clin Microbiol Infect. 2015;21:1020-1026.

9. Murphy DG, Sablon E, Chamberland J, Fournier E, Dandavino R, Tremblay CL. Hepatitis C virus genotype 7, a new genotype originating from central Africa J Clin Microbiol. 2015;53:967-72.

10. Smith DB, Bukh J, Kuiken C, Muerhoff AS, Rice CM, Stapleton JT, Simmonds P. Expanded classification of hepatitis $C$ virus into 7 genotypes and 67 subtypes: updated criteria and genotype assignment web resource. Hepatology. 2014;59:318-327.

11. Messina JP, Humphreys I, Flaxman A, Brown A, Cooke GS, Pybus OG, Barnes E. Global distributionand prevalence of hepatitis $C$ virus genotypes. Hepatology. 2015;61:77-87.

12. Ergunay $K$, Abacioglu $H$. Clinical impact of hepatitis $C$ virus genomic variations. Mikrobiyol Bul. 2015;49:625-635.

13. Abacioglu YH, Davidson F, Tuncer S, Yap PL, Ustacelebi S, Yulug $\mathrm{N}$, Simmonds P. The distribution of hepatitis $\mathrm{C}$ virus genotypes in Turkish patients. J Viral Hepat. 1995;2:297-301.

14. Yarkin F, Hafta A. The distribution of hepatitis C virus (HCV) genotypes in patients with chronic hepatitis $C$ infection. Viral Hepat J. 2000;6:164-168.

15. Bozdayi AM, Aslan N, Bozdayi G, Türkyilmaz AR, Sengezer $T$ Wend U, Erkan O, Aydemir F, Zakirhodjaev S, Orucov S, Bozkaya H, Gerlich W, Karayalçin S, Yurdaydin C, Uzunalimoglu O. Molecular epidemiology of hepatitis $B, C$ and $D$ viruses in Turkish patients. Arch Virol. 2004;149:2115-2129.

16. Altuglu I, Soyler I, Ozacar T, Erensoy S. Distribution of hepatitis C virus genotypes in patients with chronic hepatitis $\mathrm{C}$ infection in Western Turkey. Int J Infect Dis. 2008;12:239-244.

17. Gokahmetoglu S, Atalay MA, Kilınc A. Determination of the hepatitis C virus genotypes with 'pyrosequencing' method. Erciyes Med J. 2011;33:99-102.

18. Buruk CK, Bayramoglu G, Reis A, Kaklikkaya N, Tosun I, Aydin F. Determination of hepatitis $C$ virus genotypes among hepatitis c patients in eastern black sea region, Turkey Mikrobiyol Bul 2013;47:650-657.

19. Altuglu I, Sertoz R, Aksoy A, Gursel D, Tuzuner U, Gunsar F. Possible transmission risks and genotype distribution of hepatitis $C$ virus infection in Western Turkey Turk J Gastroenterol. 2013;24:349-355.

20. Saglik I, Mutlu D, Ongut G, Inan D, Ogunc D, Sarinoglu RC, Baysan BO, Gultekin M, Colak D. Distribution of hepatitis C virus genotypes among patients with chronic hepatitis $\mathrm{C}$ infection in Akdeniz University Hospital, Antalya, Turkey: A five-year evaluation. Mikrobiyol Bul. 2014;48:429-437.

21. Kuscu F, Komur S, Inal AS, Ulu AC, Kurtaran B, Taşova $Y$, Unlu B, Mıdıkı D, Tombul ZD, Yilmaz G, Suntur BM, Aksu HSZ. Changing epidemiology of chronic hepatitis C in Adana. Viral Hepatitis Journal. 2014;20:15-18.

22. Calıskan A, Kirisci O, Ozkaya E, Ozden S, Tumer S, Caglar S, Guler SA, Senol H. Distribution and predominance of genotype 3 in hepatitis $\mathrm{C}$ virus carriers in the province of Kahramanmaras. Turkey Hepat Mon. 2015;15:e25142.

23. Kirdar S, Yasa MH, Aydin N, Korkmazgil BG, Ozturk S, Omurlu IK. The distribution of hepatitis $\mathrm{C}$ virus genotypes in patients with chronic hepatitis C infection. Meandros Med Dent J. 2015;16:108-113. 
24. Kayman T, Polat C, Ergor G, Abacioglu YH. Characterization of HCV genotype 4d infections in Kayseri, Turkey. Turk J Med Sci. 2015;45:547-552.

25. Duran AC, Kibar F, Cetiner S, Yaman A. Determination of Hepatitis $C$ virus genotype and $\mathrm{HCV}$ infection transmission routes in Cukurova University Medical Faculty Hospital. Turk Hij Den Biyol Derg. 2017;74:201-210.
26. Balin SO, Tartar AS, Akbulut A, Toraman ZA. Distribution of hepatitis $C$ virus genotype in Elazıg and the relantionship between HCV RNA and serum alanine aminotransferase levels with genotype. ANKEM Derg. 2017;31:48-52.

27. Harman R, Gunal O, Ozger S. Hepatitis $C$ virus genotype distribution in patients with chronic hepatitis C in Gaziantep province Klimik Derg. 2017;30:68-67. 